\title{
Photoacoustic Signal of Nanobubbles Induced in PEGylated Gold-Nanorod Colloid
}

\author{
Istas Pratomo Manalu \\ Computer Engineering, Faculty of Informatics and Electrical Engineering \\ Institut Teknologi Del, Tobasamosir, North Sumatra 22381 \\ E-mail: istas.manalu@del.ac.id \\ Masuk: 8 Februari 2018 Direvisi: 31 Maret 2018 Disetujui :28 Mei 2018
}

\begin{abstract}
We have developed a photoacoustic (PA) measurement system using a broadband ultrasonic transducer to detect the PA signals induced in a gold nanorod (GNRs) colloid irradiated by the nanosecond-pulsed laser beam. This study will investigate the PA signals of PEG-GNRs at longitudinal surface plasmon resonance. Several factors including aspect ratio of GNR, pulse energy, concentration, and wavelength are varied to investigate these effects on the PA signal. We show that at the certain condition the generated PA signal of PEG-GNRs stronger than uncoated GNRs. Moreover, the PA signals of PEGGNRs are more stable than uncoated GNRs in the same condition.
\end{abstract}

Keywords: Gold nanorod, photoacoustic signal, PEGylated, longitudinal surface plasmon resonance, nanobubbles

\begin{abstract}
Abstrak: Kami telah mengembangkan sistem pengukuran photoacoustic (PA) menggunakan broadband ultrasonic transducer untuk mendeteksi sinyal PA yang diinduksi dalam koloid emas nanorod (GNRs) yang diiradiasi oleh nanosecond-pulsed laser beam. Studi ini akan menyelidiki sinyal PA dari PEG-GNRs pada longitudinal surface plasmon resonance. Beberapa faktor termasuk rasio aspek GNR, energi pulsa, konsentrasi, dan panjang gelombang divariasikan untuk menyelidiki efek tersebut pada sinyal PA. Kami menunjukkan bahwa pada kondisi tertentu sinyal PA yang dihasilkan dari PEG-GNR lebih kuat daripada GNR yang tidak dilapisi. Selain itu, sinyal PA dari PEG-GNRs lebih stabil daripada GNR yang tidak dilapisi dalam kondisi yang sama.
\end{abstract}

Kata kunci: Gold nanorod, photoacoustic signal, PEGylated, longitudinal surface plasmon resonance, nanobubbles

\section{INTRODUCTION}

Photoacoustic (PA) imaging is a breakthrough technique for determining the location of tumors in living cells with the aid of a light-absorbing compound known as a contrast agent. Generating a PA signal requires an ultrafast laser pulse to illuminate a small area of living tissue. This creates a series of molecular vibrations that generate ultrasonic sound waves in the sample. PA imaging is particularly useful for biomedical applications when 3D optical absorption maps of biological structures are needed to reconstruct and visualize the inner structures of complex objects, such as the brain and cardiovascular system [1]. Diagnosing cancers with PA imaging requires contrast agents that can penetrate tissue and are selectively bound to malignant cells. In addition, contrast agents require high optical responses near infrared that have a very safe spectral region for biological materials. However, the natural contrast present in this biological structure may not be enough to produce a significant PA signal so that researchers try to find other alternatives by introducing artificial contrast agents to improve from these deficiencies. As soon as this agent is bonded to a place of interest, the local contrast is increased and hence the PA amplitude is increased simultaneously.

Metal nanoparticles are proven to be good contrast agents in PA imaging cases. Recently, Metal nanoparticles (MNPs) are the focus of interest because of their huge potential in nanotechnology [2-6]. These nanoparticles are scientifically interesting owing to their size and shape dependent physical as well as chemical properties. As a class of materials, many MNPs attract attention mainly to electrical, optical, and biomedical applications [7]. Due 
to the ease of surface modification of metallic nanoparticles, a number of varied coatings and shells can be applied to nanoparticle synthesis. This surface modification can be enabled for a number of applications in sensing[4], [5], [8-11], medicine[12-18], and characterization[17], [19], [20].

\section{THEORY}

\section{Principle of Photoacoustic Effect}

Photoacoustics (PA) also known as optoacoustic, is a technique that maps acoustic signals generated from elastic thermal expansion in rapidly-modulated light absorption (laser) [21], [22]. The technique was first introduced by A. G. Bell in 1880 [22], [23], [24-28]. But the PA effect has recently grown rapidly in a number of areas, ranging from basic science to engineering [26], [29].

PA imaging is particularly useful in determining the location of the tumor, monitoring heterogeneity in the blood vessels within it and monitoring the accumulation of therapeutic agents. Through this new development technique, photoacoustic imaging and photothermal therapy (PTT) utilized in various medical areas such as cancer. The absorption and scattering of surface plasmons that contribute to the well are capable of determining the extinction band of the gold nanoparticles depending on the composition of the material, shape, and environment of the nanoparticles. GNR is very attractive because they are small, easily synthesized, have a resonance in the red and NIR spectra, and have a very high cross section. During GNRs exposed to high-energy nanosecond laser pulses, nanorods absorb some of the energy and generate substantial heat, which can lead to nanorod reformation and reduction of associated cross section absorption.

\section{EXPERIMENT}

\section{Sample Preparation}

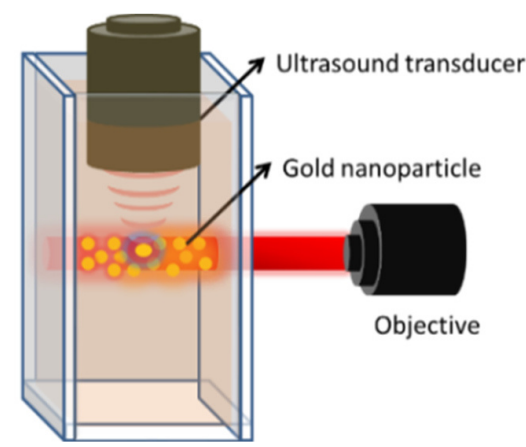

Figure 1. Schematic illustrations of laser induce nanobubble in the gold colloid.

Before doing the experiments, samples were stirred using a vortex machine to prevent aggregation or grouping of nanoparticles for 1 minute. Then send each sample to a high vacuum pump. For this study, the degassed water and colloids were used for avoiding the solved gas in water to form permanent bubbles.

\section{RESULT AND DISCUSSION}

\section{Characterization of Material}

We performed PA signal measurements using PEG@GNR under different conditions with bare GNRs. The optical spectra (Figure 2a) of the particles before and after PEGylation show that the characteristic plasmon peaks are preserved and that the colloid is stable. The longitudinal peak of PEG is located at $963 \mathrm{~nm}$ with the average sizes of the PEG@GNRs and aspect ratio are about $94.95 \pm 14.64 \mathrm{~nm}$ and $6.66 \pm 1.26$. The surface plasmon resonance has been observed of the PEG@GNRs by using optical absorption, and it is located at $963 \mathrm{~nm}$. As a comparison, we also prepared uncoated GNR which has the same longitudinal peak value at $963 \mathrm{~nm}$. The particles retain excellent dispersion stability even after mixing in cell culture medium showing that the PEGylation forms a strong link to the gold surface, and the composite is not affected by cell medium contents. PEGylated particles elicited excellent cell viability and were essentially non-toxic. 

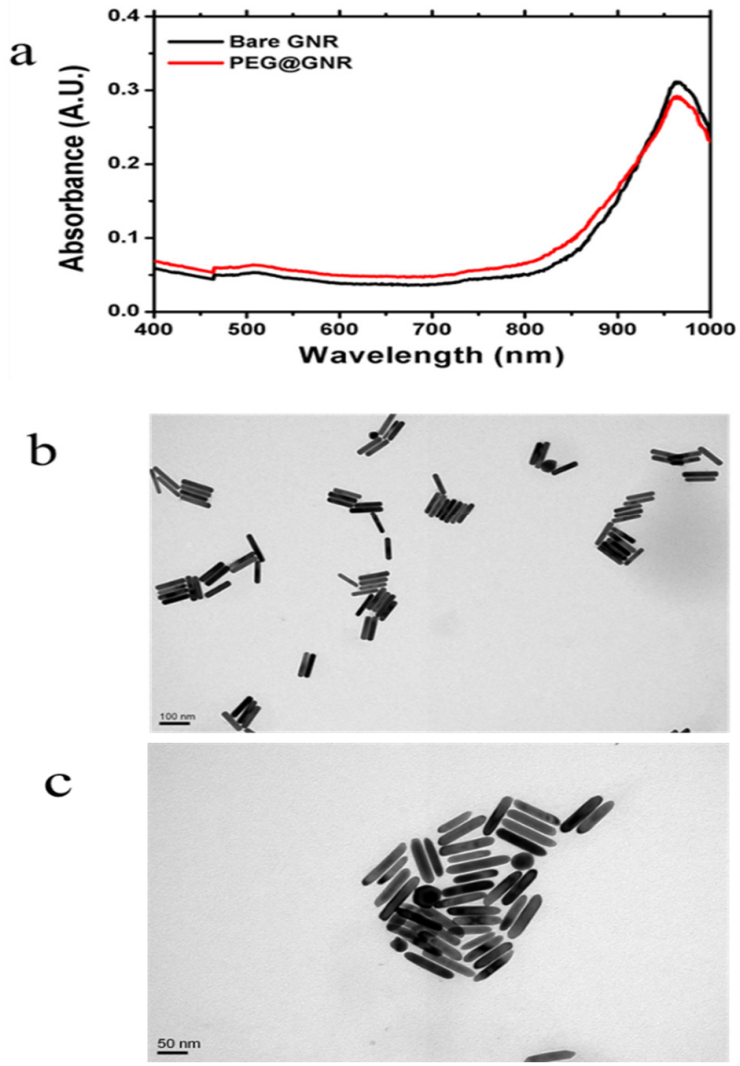

Figure 2. (a) Optical extinction spectrum of uncoated GNRs with longitudinal plasmon (black line) and PEG@GNR 963 nm (red line) before irradiation. TEM image of (b) uncoated PEG@GNR and (c) uncoated GNR

\section{Photoacoustic Signal Generation of Uncoated GNR 963 nm and PEGylated@GNR}

GNR is usually produced by simple seed-mediated chemical reactions and cetyltrimethylammonium bromide (CTAB) surfactants that are directed synthesis. However, many studies have found that after the reaction, some CTABs remain attached to the surface of the GNRs. This has a fairly serious effect because a large number of CTAB present in the solution interferes with biological processes and shows high cytotoxicity. Releasing CTAB from the surface can cause aggregation of uncontrolled GNRs [30]. The modification of GNR surfaces has been the focus of a number of recent researchers to provide stability, solubility, and optical properties retention in various media and reduce cytotoxicity. One of these modifications known as polyethylene glycol (PEG) is a general strategy for preparing biocompatible materials. PEG modification was found as an excellent alternative method for removal of CTAB and stabilizing nanorods in physiological conditions [30], [31].

\section{As a Function of Concentration}

In this study, we also tested photoacoustic signal generation from PEG@GNRs at longitudinal surface plasmon $963 \mathrm{~nm}$. These spectra also remain stable in time as tested over several months. Using the same experimental system, we were able to obtain photoacoustic information from this sample. To observe the amplitude of photoacoustic signals related to the concentration of nanoparticles and laser energy, the incident photoacoustic signals with three different concentrations of PEG@GNR (2 ppm, 4 ppm, and 8 ppm) at 963 nm LSPR were obtained with laser energy varying from $0.4 \mathrm{~mJ}-3.5 \mathrm{~mJ}$ at a wavelength of $963 \mathrm{~nm}$. As a standard comparison, uncoated GNR also presented at a wavelength of $963 \mathrm{~nm}$ with each measurement repeated four times (not shown). Each repetition of the measurement involves a new sample with the same optical properties placed in the cuvette. The repeatability of the measurements showed that the suspensions of the particles were uniform and the photoacoustic excitation did not show any significant change in the particle suspension. 

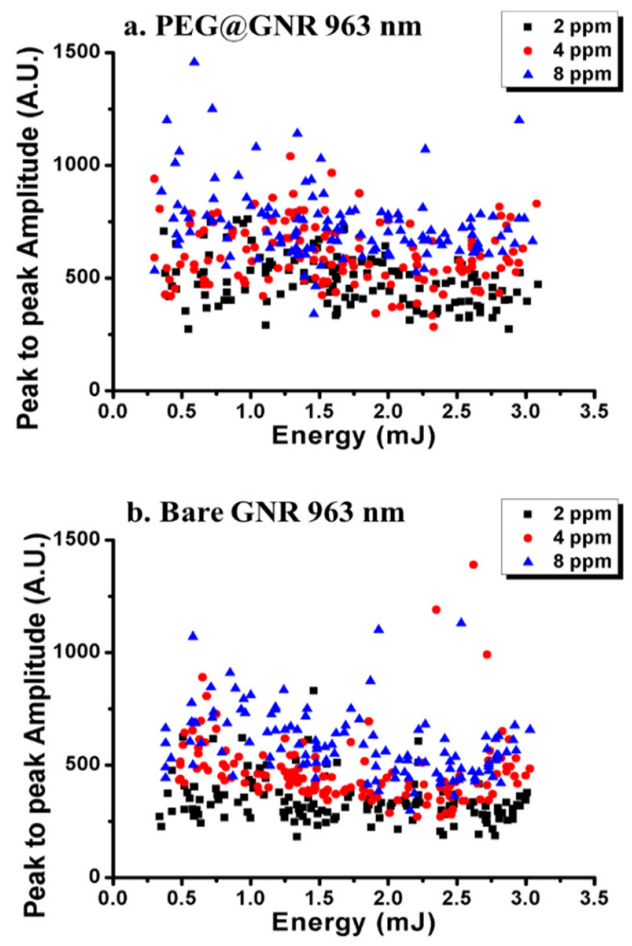

Figure 3. Photoacoustic signal intensity of (a) uncoated GNRs $963 \mathrm{~nm}$ and (b) PEG-coated GNRs versus laser energy as a function of concentrations.

The result shows that PA signal is found to be proportional to the number of absorbers; simply, a larger nanoparticle concentration can lead to increased nanoparticle accumulation in the focal region. As a result, more absorbers will increase the PA signal. In fact, until now, extremely few relevant studies have assessed the photoacoustic behavior of GNRs under repeatable experimental conditions.

In the case of clinical application, the benefit of PEGylation by using systemic injection is to increase the circulatory time to improve accumulation at tumor sites. Targeting through antibody conjugation can also provide an increased accumulation at desired location and increase the specificity to allow molecular imaging to be performed.

\section{CONCLUSIONS}

In this study, the photoacoustic signals of the pulsed-laser induced nanobubbles in the bare GNRs (963 nm) andPEG@GNRs colloids were studied. Our results show that the PA signal of the nanobubbles induced by pulsed laser in gold colloids increases as the concentration decreases. To explain this phenomenon, a reasonable assumption is proposed that the absorption of energy by GNRs to produce cavitation bubbles at the focal point is influenced by the light scattering in the optical path to cause a slight defocusing of the Gaussian beam. This is due to the Faraday-Tyndall effect. We suspect that by adding a layer of material to the GNR surface with a limited heat and conduction capacity (high resistivity) will only expand the heat dissipation of GNR to enter the surrounding medium and deteriorate the PA signal.. As a result, the PEG-gold In this study, the morphology and phase of coating were strongly correlated to the hardness nanorods show to be a promising candidate for molecular photoacoustic imaging.

\section{REFERENCE}

[1] Pérez-Cota F, Smith R J, Moradi E, Marques L and Webb K F 2016 Sci. Rep. 639326

[2] Reviewed P, Optics N and Therapy P T 2013 Electronic Thesis and Dissertations Los Angeles Design and Synthesis of Plasmonic Core / Shell Nanorods for Light Trapping in Organic Photo-Voltaics, Non-Linear Optics and Photo-Thermal Therapy A dissertation submitted in partial satisfaction of the requ 
[3] Terentyuk G et al. 2014 Nano Res. 7(3) 325

[4] Biswas A, Wang T and Biris A S 2010 Nanoscale 2(9) 1560

[5] Jana J et al. 2016 RSC Adv. 6(89) 86174

[6] Li J, Guo H and Li Z-Y, 2013Microscopic and macroscopic manipulation of gold nanorod and its hybrid nanostructures [Invited]

[7] Törngren B et al. 2014 J. Colloid Interface Sci. 42754

[8] Gao F, Feng X and Zheng Y 2016 One laser pulse generates two photoacoustic signals 1

[9] James J, Murukeshan V M and Who L S 2014 Biomed. Opt. Express 5(7) 2135

[10] Cao J, Sun T and Grattan K T V 2014 Sensors Actuators, B Chem. 195332

[11] Jayabal S, Pandikumar A, Lim H N, Ramaraj R, Sun T and Huang N M 2015 Analyst 140(8) 2540

[12] Priya M, Satish Rao B S, Ray S and Mahato K K 2014 Spectrochim. Acta - Part A Mol. Biomol. Spectrosc. 12785

[13] Luke G P, Nam S Y and Emelianov S Y 2013 Photoacoustics 1(2) 36

[14] Feis A, Gellini C, Salvi P R and Becucci M 2014 Photoacoustics 2(1) 47

[15] Spagnolo V 2014 Sensors (Basel). 14(4) 6165

[16] Viator J and Viator J 2000 Sci. Technol.

[17] Walker M E R 2012 Synthetic routes to silica-coated gold nanorods 1

[18] Huang C -J, Chiu P -H, Wang Y -H, Chen W -R, Meen T -H and Yang C -F, 2006 Nanotechnology 17(21) 5355

[19] Sarimollaoglu M, Nedosekin D A, Menyaev Y A, Juratli M A and Zharov V P 2014 Photoacoustics 2(1) 1

[20] Strohm E M, Berndl E S L and Kolios M C 2013 Photoacoustics 1(3-4) 49

[21] Yasun E et al. 2013 Interface Focus 3(3) 20130006

[22] Beard P 2011 Interface Focus 1(4) 602

[23] Kruizinga P 2010 Contrast enhancement in photoacoustic imaging

[24] Title P T 1947 Doctoral Thesis Research Proposal Carbon N. Y. 1

[25] Liu X Nanoparticles and Surface-Enhanced Optical Effects for Chemical and Biological Sensing

[26] Li W and Chen X 2015 Nanomedicine 10(2) 299

[27] Manuscript A and Nanostructures S P C 2008 Nano 6(9) 2166

[28] Gorman M E 1947 Nature 159(4035) 297

[29] Li C and Wang L V 2009 Phys. Med. Biol. 54(19) 59

[30] Schulz F, Friedrich W, Hoppe K, Vossmeyer T, Weller H and Lange H 2016 Nanoscale 8

[31] Huang H -C, Rege K and Heys J J 2010 ACS Nano 4(5) 2892 